\title{
HIV infection in mobile populations: the case of Mexican migrants to the United States
}

\author{
Ana P. Martínez-Donate, ${ }^{1}$ M. Gudelia Rangel, ${ }^{2}$ Melbourne F. Hovell, ${ }^{1}$ \\ Jorge Santibáñez, ${ }^{2}$ Carol L. Sipan, ${ }^{2}$ and José A. Izazola ${ }^{3}$
}

Suggested citation Martínez-Donate AP, Rangel MG, Hovell MF, Santibáñez J, Sipan CL, Izazola JA. HIV infection in mobile populations: the case of Mexican migrants to the United States. Rev Panam Salud Publica. 2005; 17(1):26-9.

\begin{abstract}
Objective. Previous studies have indicated varying rates of HIV infection among labor migrants to the United States of America. Most of these studies have been conducted with convenience samples of farmworkers, thus presenting limited external validity. This study sought to estimate the prevalence of HIV infection and risk factors among Mexican migrants traveling through the border region of Tijuana, Baja California, Mexico, and San Diego, California, United States. This region handles 37\% of the migrant flow between Mexico and the United States and represents the natural port of entry for Mexican migrants to California.

Methods. From April to December 2002 a probability survey was conducted at key migrant crossing points in Tijuana. Mexican migrants, including ones with a history of illegal migration to the United States, completed an interview on HIV risk factors $(\mathrm{n}=1429)$ and an oral HIV antibody test $(\mathrm{n}=1041)$.

Results. Despite reporting risk factors for HIV infection, none of the migrants tested positive for HIV.

Conclusions. Our findings contrast with previous estimates of HIV among labor migrants in the United States that were based on nonprobability samples. Our findings also underline the need for early HIV prevention interventions targeting this population of Mexican migrants.
\end{abstract}

Key words HIV infections, sexually transmitted diseases, transients and migrants, risk factors, sexual behavior, Mexico, United States of America.

1 San Diego State University, Center for Behavioral Epidemiology and Community Health, San Diego, California, United States of America. Address correspondence and reprint requests to: Ana $P$. Martínez-Donate, C-BEACH, Graduate School of Public Health, San Diego State University, 9245 Sky Park Court, Suite 230, San Diego, California 92123, United States of America; telephone: (858) 5054770 x111; fax: (858) 505-8614; e-mail: amartinez@ projects.sdsu.edu

2 El Colegio de la Frontera Norte, San Antonio del Mar, Baja California, México.

3 Fundación Mexicana para la Salud, México, Distrito Federal, México.
Previous studies (1-3) suggest increased rates of HIV infection and related risk factors among labor migrants in the United States of America. However, existing data are outdated and based on nonprobability samples. In addition, although Mexicans represent the majority of labor migrants in the United States, most research has included only small subsamples of Mexican migrants. For instance, stud- ies conducted in eastern areas of the United States on HIV among migrant and seasonal farmworkers included few or no migrants of Mexican origin (4-7). Most migrants in these studies were either non-Hispanic AfricanAmericans or Haitians. In other studies, no information on the percentage of Mexican migrants within the sample was reported (1). Finally, no HIVinfected individuals were found in 
research conducted with mostly Mexican migrant workers in western regions of the United States. ${ }^{4}$ Epidemiological studies on HIV and migration from Mexico to the United States are hampered by the itinerant nature of migrants, their geographic spread within the country of origin and country of destination, and, in some cases, their illegal migration status in the United States. Inaccurate estimates may jeopardize the development of appropriate health and migration policies in both Mexico and the United States. The lack of reliable epidemiological data may also increase prejudices against Mexican migrants in both countries.

This piece describes the findings from a survey of HIV infection and related risk factors among Mexican migrants traveling through the border region of the cities of Tijuana, Baja California, Mexico, and San Diego, California, United States. Our survey used the methodology and infrastructure of an ongoing Mexican survey, the Survey on Migration in the Northern Border of Mexico (Encuesta sobre Migración en la Frontera Norte de México). Tijuana handles $37 \%$ of the total migrant flow between Mexico and the United States and $71 \%$ of the total migrant flow between Mexico and the United States in the western region of the United States-Mexico border (8).

The Survey on Migration has been conducted at key crossing sites of eight Mexican border cities since 1993. The survey uses a multistage probability sampling design that entails the screening, accurate enumeration, and recruitment of samples uniquely representative of the migrant population traveling through the United States-Mexico border region, thus allowing computation of population estimates. A detailed description of the survey methodology has been published elsewhere $(9,10)$.

\footnotetext{
4 Ruiz JD, Da Valle L, Jungkeit M, Platek G, Mobed K, Lopez R. Seroprevalence of HIV and syphilis and assessment of risk behaviors among migrant and seasonal farmworkers in five Northern California counties. [Unpublished report]. Office of AIDS, HIV/AIDS Epidemiology Branch, California Department of Health Services; 1997.
}

The Survey on Migration collects information from representative samples of four key subpopulations: (1) migrants returning to Mexico from the United States, (2) migrants arriving to the Mexican border region from other, nonborder Mexican regions, (3) migrants arriving to one Mexican border region (e.g., Tijuana) from another Mexican border region (e.g., Ciudad Juárez), and (4) migrants returned to Mexico by the United States Border Patrol.

From April to December 2002 the Survey on Migration was extended with a survey on HIV risk behaviors and with antibody testing in Tijuana, using survey sites at the Tijuana International Airport, four Tijuana bus stations, and the Tijuana deportation stations. (Deported Mexican migrants are usually returned by the United States Border Patrol to Mexican migration authorities stationed at the northern border of Mexico. If the migrants are free of other charges, they are then released from the Mexican deportation stations. There are two Mexican deportation stations in Tijuana.)

After completion of the migration survey, 1606 adult Survey on Migration participants were invited to complete the additional survey on HIV and an oral HIV antibody test. Of those invited, 1429 (89.0\%) completed the questionnaire on HIV risk factors, and $1041(64.8 \%)$ were tested for the presence of HIV antibodies. The 1429 were made up of 1248 males $(87.3 \%)$ and 181 females $(12.7 \%)$, with a mean age of 33.2 years (standard deviation $(\mathrm{SD})=11.8$ years). The mean number of years of education was $7.5(\mathrm{SD}=4.1$ years), with $5.8 \%$ of the participants reporting being illiterate. About 8.5\% of the surveyed migrants reported being able to speak a Mexican Indian language, in addition to Spanish. Just short of two-thirds (66.4\%) of the participants were married, and 58.6\% had a history of migration to the United States. While $78.7 \%$ of the participants reported living in Mexico (the sample included migrants from all 32 states of Mexico), a substantial percentage $(21.2 \%)$ reported residing in the United States. One subject reported residing in another country.
Factors related to HIV risk were assessed through self-report questions. Oral transudate samples were collected by means of the OraSure HIV-1 Oral Specimen Collection Device (OraSure Technologies, Bethlehem, Pennsylvania, United States) and sent for analysis to the Public Health Laboratory of the Health and Human Services Agency of San Diego County. Confirmatory testing using the Western Blot method was applied to positive specimens. Pretest counseling was provided prior to specimen collection, following standards from the Centers for Disease Control and Prevention of the United States.

The validity of the testing procedures, handling of biological samples, and laboratory testing were checked formally by testing two study confederates of known HIV-positive status. The confederates were two HIVpositive patients from a Tijuana HIV clinic, recruited by a physician collaborating with this study. These patients were not part of our HIV survey or the Survey on Migration. The project staff and laboratory personnel were kept blind to the confederate condition and HIV status of these two subjects. The two confederates were tested by project staff as if they were any other study participants. The results correctly identified as positive the samples obtained from the two confederates, thus supporting the validity of the study's HIV screening procedures and ability to identify HIV-positive cases.

Table 1 displays weighted prevalence estimates and standard errors of reported HIV-related lifetime risk factors and risk practices during the preceding six months, for each of the four migrant subpopulations. The lifetime rates of sexually transmitted infections (STIs) ranged from 5.3\% to $8.2 \%$ among the four subpopulations.

In contrast with the prevalence rates found for STIs and other risk factors, none of the 1041 individuals tested positive for HIV infection, with 1040 samples resulting negative and 1 yielding indeterminate results. The prevalence rate of HIV infection among this sample of migrants was lower than $0.10 \%$ (i.e., less than 1 out of 
TABLE 1. Population estimates of the prevalence of HIV risk factors and practices by subpopulations of Mexican migrants to the United States, studied in Tijuana, Mexico, 2002

\begin{tabular}{|c|c|c|c|c|c|c|c|c|}
\hline & \multicolumn{2}{|c|}{$\begin{array}{l}\text { U.S.-Mexico } \\
\quad(n=497)\end{array}$} & \multicolumn{2}{|c|}{$\begin{array}{l}\text { South-North } \\
\quad(n=485)\end{array}$} & \multicolumn{2}{|c|}{$\begin{array}{l}\text { Border region }{ }^{c} \\
\quad(n=280)\end{array}$} & \multicolumn{2}{|c|}{$\begin{array}{l}\text { Deported }^{d} \\
(n=167)\end{array}$} \\
\hline & $\%$ & $\mathrm{SE}^{\mathrm{e}}$ & $\%$ & SE & $\%$ & SE & $\%$ & SE \\
\hline History of HIV testing & 37.3 & 3.5 & 28.2 & 2.9 & 26.2 & 3.5 & 35.0 & 5.0 \\
\hline Never heard of HIV & 6.1 & 1.3 & 6.2 & 1.4 & 7.5 & 2.9 & 7.5 & 2.6 \\
\hline \multicolumn{9}{|l|}{ Perception of risk for $\mathrm{HIV}^{f}$} \\
\hline Vaginal, anal, or oral sex in last $6 \mathrm{mo}$ & 59.4 & 3.5 & 72.0 & 2.9 & 70.7 & 3.9 & 58.0 & 5.1 \\
\hline Multiple sexual partners in last 6 mo & 9.6 & 2.3 & 12.5 & 1.9 & 18.8 & 3.5 & 15.3 & 4.1 \\
\hline & 44.5 & 3.6 & 60.4 & 3.2 & 52.9 & 4.2 & 46.0 & 5.2 \\
\hline \multicolumn{9}{|l|}{ Multiple partners and unprotected vaginal } \\
\hline 位 & 1.0 & 2.2 & $0 . c^{2}$ & 1.0 & 10.1 & 2.0 & 0.5 & 2.5 \\
\hline
\end{tabular}

$1040)$. A comparison of the risk profiles of the tested subsample who completed the HIV questionnaire (1010 persons) vs. the nontested subsample who completed the HIV questionnaire (419 persons) indicated that the migrants tested for HIV were more likely to report multiple sexual partners during the preceding six months (14.1\% vs. $8.3 \%, P<0.01)$. This difference suggests that the nontested subsample was at lower risk for HIV than the tested subsample and, therefore, HIV prevalence might be lower among the nontested subsample.

The lifetime rate of STIs estimated for the entire migrant population that we studied in Tijuana is comparable to the rates that previous research has found for Mexican migrants in the western region of the United States (Ruiz et al., unpublished, 1997) and for the adult population in Mexico (11). However, our estimated rate of STIs for Mexican migrants is much lower than estimations based on surveys of migrants from the eastern agricultural areas of the United States $(4,5)$, which included lower proportions of Mexicans.

In contrast with the prevalence of STIs and other risk factors, the prevalence of HIV infection among the pop- ulation of Mexican migrants in the Tijuana-San Diego border region does not appear to be as high as previously suggested by studies of convenience samples of labor migrants in the eastern United States (4-7), and it may be even lower than HIV rates among the adult Mexican population $(12,13)$. This is plausible given that HIV rates in Mexico are higher in large urban areas and among men who have sex with men $(11,14)$, while Mexican migrants mostly originate from rural areas.

The contrast between the estimated prevalence of HIV risk factors and the absence of HIV infection among the migrant population we have studied represents an interesting paradox and may suggest that Mexican migrants may have some unidentified characteristics that "protect" them from higher rates of HIV infection, despite their levels of sexual risk practices. For one thing, HIV infection might not yet be endemic among the sexual partners of Mexican migrants due to yetunknown epidemiological and cultural factors, including possible social isolation from infected people. Additional research should examine the characteristics of the migrants' sexual network. Furthermore, future research with probability-based samples should study whether the paradox of low HIV rates and high levels of risk factors generalizes to all Mexican migrants to the United States and not just to those traveling through the Tijuana-San Diego border region.

The presence of low rates of HIV infection within the context of HIV risk behaviors underscores the need for surveillance and early prevention interventions before HIV becomes epidemic among Mexican migrants. These findings also highlight the importance of conducting probability-based surveys to obtain a more accurate picture of HIV infection in this population.

Acknowledgements. This research was supported by grant CR01CBECH-100 awarded to Melbourne F. Hovell and M. Gudelia Rangel by the Universitywide AIDS Research Program (UARP), University of California. We would like to thank Armando Rosas, Carlos Vera, and Ana Chairez for their contribution to the implementation of the survey and processing of the study data. We greatly appreciate Liza Rovniak and several anonymous reviewers for their helpful comments on earlier versions of this paper. 


\section{REFERENCES}

1. Castro KG, Narkunas JP. Seroprevalence of HIV infection in seasonal and migrant farmworkers: preliminary results. Migr Health Newsline Clin Supplement 1989;6(4):49-50.

2. Organista KC, Organista PB. Migrant laborers and AIDS in the United States: a review of the literature. AIDS Educ Prev. 1997;9(1): 83-93.

3. Wong W, Tambis JA, Hernandez MT, Chaw JK, Klausner JD. Prevalence of sexually transmitted diseases among Latino immigrant day laborers in an urban setting-San Francisco. Sex Transm Dis. 2003;30(8):661-3.

4. Castro KG, Lieb S, Jaffe HW, Narkunas JP, Calisher $\mathrm{CH}$, Bush TJ, et al. Transmission of HIV in Bell Glade, Florida: lessons for other communities in the United States. Science. 1988;239:193-7.

5. Jones JL, Rion P, Hollis S, Longshore S, Leverette WB, Ziff L. HIV-related characteristics of migrant workers in rural South Carolina. South Med J. 1991;84(9):1088-90.

6. United States of America, Centers for Disease Control and Prevention. HIV seroprevalence in migrant and seasonal farmworkers-North Carolina, 1987. MMWR. 1988;37:517-9.

7. United States of America, Centers for Disease Control and Prevention. HIV infection, syph- ilis, and tuberculosis screening among migrant farm workers-Florida, 1992. MMWR. 1992;41(39):723-5.

8. Secretaría del Trabajo y Previsión Social, Consejo Nacional de Población, El Colegio de la Frontera Norte. Encuesta sobre Migración en la Frontera Norte de México 1996-1997. México, D.F.: Secretaría del Trabajo y Previsión Social; 1999.

9. Santibáñez J. Metodología de la Encuesta sobre Migración en la Frontera Norte de México. In: Bustamante JA, Delaunay D, Santibáñez J, eds. Taller de medición de la migración internacional. Tijuana: El Colegio de la Frontera Norte, ORSTOM; 1997. Pp. 206-29.

10. Secretaría del Trabajo y Previsión Social, Consejo Nacional de Población, El Colegio de la Frontera Norte. Encuesta sobre Migración en la Frontera Norte de México 1999-2000. México, D.F.: Secretaría del Trabajo y Previsión Social; 2002.

11. Consejo Nacional de Prevención y Control en México. Las cifras del SIDA en México [press release]. Consejo Nacional de Prevención y Control en México, Secretaría de Salud, August 2002. Available from: http://www. salud.gob.mx/conasida/otraspub/letraese/ ls2002/lsago.htm. Accessed 16 January 2004.
12. Izazola-Licea JA, Gortmaker SL, Tolbert K, Gruttola V, Mann J. Prevalence of samegender sexual behavior and HIV in a probability household survey in Mexican men. J Sex Res. 2000;37(1):37-43.

13. Joint United Nations Programme on HIV/ AIDS. Mexico. 2004 update. Epidemiological fact sheets on HIV/AIDS and sexually transmitted infections. Geneva: UNAIDS; 2004 Available from: http://www.unaids.org/ $\mathrm{html} / \mathrm{pub} /$ publications/fact-sheets01/ mexico_en_pdf.htm [Web site]. Accessed 17 November 2004.

14. Bravo-García E, Magis Rodríguez C. El SIDA en el área rural. In: Magis C, Bravo-García E, Carrillo AM, eds. La otra epidemia: el SIDA en el área rural. México, D.F.: Centro Nacional para la Prevención y Control del VIH/SIDA; 2003. Pp. 11-18. Available from: http:/ / www. modemmujer.org/011203/docs/otraepid.pdf [Web site]. Accessed 17 November 2004.

Manuscript received 20 May 2004. Revised version accepted for publication on 9 September 2004.

RESUMEN Objetivo. Estudios anteriores han revelado diferentes tasas de infección por VIH en la población de obreros itinerantes que han ingresado en los Estados Unidos de América. La mayoría de esos estudios se efectuaron con muestras de trabajadores agrícolas tomadas por conveniencia, y por lo tanto su validez externa ha sido limitada. El presente estudio se realizó con el fin de calcular la prevalencia de la infección por VIH y de sus factores de riesgo en los obreros itinerantes mexicanos que se desplazan por el territorio fronterizo de Tijuana, Baja California, México y San Diego, California, Estados Unidos. Esta zona, por donde pasan 37\% de los obreros itinerantes que vienen de México a los Estados Unidos, es el natural puerto de entrada de trabajadores mexicanos que van a California.

Métodos. De abril a diciembre de 2002 se realizó una encuesta por conveniencia en diferentes puntos clave de Tijuana por donde cruzaban la frontera los obreros itinerantes. Los obreros, entre ellos algunos con antecedentes de inmigración ilegal a los Estados Unidos, completaron una entrevista sobre los factores de riesgo de infección por VIH ( $n=1429)$ y fueron sometidos a una prueba oral para la detección de anticuerpos contra el VIH $(n=1041)$.

Resultados. Aunque los obreros indicaron tener factores de riesgo asociados con la infección por $\mathrm{VIH}$, ninguno de ellos tuvo un resultado positivo en la prueba detectora de VIH.

Conclusiones. Estos resultados difieren radicalmente de los obtenidos anteriormente al usar muestras no probabilísticas para calcular la tasa de infección por VIH en obreros itinerantes en los Estados Unidos. Resaltan, además, la necesidad de llevar a cabo intervenciones tempranas para prevenir la infección por VIH en obreros itinerantes mexicanos.

Palabras clave Infecciones por VIH, enfermedades sexualmente transmisibles, transeúntes y migrantes, factores de riesgo, conducta sexual, México, Estados Unidos. 